\title{
Characterization of aryl hydrocarbon receptor agonists in sediments of Wenyu River, Beijing, China
}

\author{
Jianping Luo, Mei Ma, Jinmiao Zha, Zijian Wang*
}

State Key Laboratory of Environmental Aquatic Chemistry, Research Center for Eco-Environmental Sciences, Chinese Academy of Sciences, P.O. Box 2871, Shuangqing Road 18, Haidian District, Beijing 100085, China

\section{A R T I C L E I N F O}

\section{Article history:}

Received 29 December 2008

Received in revised form

28 February 2009

Accepted 4 March 2009

Published online 20 March 2009

\section{Keywords:}

Ah-agonist

PCDD/Fs

PCBs

PAHs

H4IIE

Sediment

\begin{abstract}
A B S T R A C T
Aryl hydrocarbon receptor agonistic (Ah-agonistic) effects of 23 sediments from Wenyu River in Beijing, China were evaluated using the H4IIE cell bioassay. Five samples were selected for chemical analysis of most concerned Ah-agonists, i.e. polychlorinated dibenzo-p-dioxins (PCDDs), dibenzofurans (PCDFs), biphenyls (PCBs), and polycyclic aromatic hydrocarbons (PAHs). All raw sediment extracts induced significant Ah-agonistic effects, and the bioassay-derived 2,3,7,8-tetrachlorodibenzo-p-dioxin (TCDD) equivalents of raw extracts (TEQ ${ }_{\text {raw }} \mathrm{s}$ ) ranged from 8.5 to $336.0 \mathrm{pg} / \mathrm{g}$ dry weight (dw). Chemical analysisderived TEQs (TEQ ${ }_{\text {chems }}$ ) ranged from 20.5 to $64.8 \mathrm{pg} / \mathrm{g} \mathrm{dw}$. When raw extracts were purified by sulphuric acid silica gel column to derive acid stable fraction, the TCDD equivalents in this fraction (TEQstables) ranged from 2.7 to $63.8 \mathrm{pg} / \mathrm{g}$ dw. PCBs, PCDDs and PCDFs contributed about $51.4-72.1 \%, 1.2-7.3 \%$, and $16.4-34.8 \%$ of $\mathrm{TEQ}_{\text {stable }} \mathrm{S}$, respectively, and the sum was $69.1-108.6 \%$. Therefore, about $65.0 \%$ of $\mathrm{TEQ}_{\text {raw }} \mathrm{s}$ could be attributed to acid labile fraction and only $3.3-9.6 \%$ to PAHs. These observations suggested that acid stable fraction and labile fraction contributed together to total Ah-agonistic effects in the sediments, and PCBs and PCDFs might be the two main components in acid stable Ah-agonists. The proposed approach using both H4IIE cell bioassay and chemical analysis could be used for characterization and prioritization of Ah-agonists in river sediments and helpful to the following progression of ecological remediation.
\end{abstract}

(c) 2009 Elsevier Ltd. All rights reserved.

\section{Introduction}

Aryl hydrocarbon receptor agonists (Ah-agonists), which include structurally diverse synthetic and naturally-occurring chemicals, are ubiquitous in the environment (Denison et al., 2002). Ah-agonists share a common mechanism of action in binding to the Ah receptor as a first step, and toxicities are produced as a result of changes in gene expression mediated Ah receptor or interference in its related signaling pathways
(Safe, 1990). In the past decades, the major concerns on Ahagonistic effects were associated with dioxins and dioxin-like compounds which mainly referred to polyhalogenated aromatic hydrocarbons (PHAHs) including polychlorinated dibenzo-pdioxins (PCDDs), dibenzofurans (PCDFs), biphenyls (PCBs), naphthalenes (PCNs) and others (reviewed by Behnisch et al., 2001). These compounds have been shown to produce a number of toxic effects upon wildlife and human health due to both the persistent behavior and ability to bioaccumulate (Van den Berg

Abbreviations: PCDD, polychlorinated dibenzo-p-dioxin; PCDF, polychlorinated dibenzofuran; PCB, biphenyl; PAH, polycyclic aromatic hydrocarbons.

* Corresponding author. Tel./fax: +861062849140.

E-mail address: wangzj@rcees.ac.cn (Z. Wang).

0043-1354/\$ - see front matter ( 2009 Elsevier Ltd. All rights reserved.

doi:10.1016/j.watres.2009.03.015 
et al., 1998; Tillitt et al., 1996). Moreover, other classes of nonhalogenated Ah-agonists (e.g. PAHs, heterocyclic oxygen- and sulfur-containing compounds, humic substances) could coexist with the dioxin-like compounds (reviewed by Behnisch et al., 2001; Bittner et al., 2006; Brack and Schirmer, 2003).

Ah-agonists enter the aquatic environment from a number of potential sources via different routes, such as effluent discharges, atmospheric deposition and runoff from roads (US EPA, 1998; Blanchard et al., 2001; Kakimoto et al., 2006). Since Ah-agonists are generally hydrophobic and have a strong affinity to sediments, the sediments are the eventual sink for these compounds. Moreover, every Ah-agonist source could have its own distinctive composition feature of Ah-agonists. Thus, the profiles of Ah-agonists in sediments may vary widely with different local discharge scenarios. Therefore, it is of great importance to characterize Ah-agonists and conduct causality analysis using appropriate approaches in risk assessments of contaminated sediments.

To characterize complex mixtures of Ah-agonists in the environmental samples, toxic equivalency factor (TEF) conception was developed (Van den Berg et al., 1998). However, for a lot of Ah-agonists their TEFs are not available or their structures and characteristics are unknown. Therefore, chemical analysis provides only part of the knowledge about the biological effects of contaminants and does not take into consideration the total effects. A variety of bioassays have been developed to estimate the total biological activity of all Ah-agonists in complex environmental matrices (Giesy et al., 2002). The H4IIE cell bioassay (Tillitt and Giesy, 1991) applied in this study are based on Ah receptor-dependent ethoxyresorufin-O-deethylase (EROD) induction. This enzymatic assay is a sensitive biomarker that has been successfully applied in characterizing and assessing the Ah-agonistic effects for the sediment and soil (Qiao et al., 2006; Shen et al., 2008; Gale et al., 2000).

Wenyu River in Beijing is a typical water system in northern China with a flow of about 5 billion $\mathrm{m}^{3}$ per year which was mainly used for receiving industrial and municipal discharges in the past years. The suspended particulates in this river can be sufficiently sedimentated due to low flow velocity (about $3.0 \mathrm{~cm} / \mathrm{s}$ ). It is imperative to assess individual classes of Ah-agonists and their contribution to overall hazards in sediments from this river for evaluating the risk and following the progression of a remediation strategy. In this study, we employed a combination of fractionation-based H4IIE cell bioassay and chemical analysis of most concerned and ubiquitous Ah-agonists, i.e., polychlorinated dibenzo- $p$ dioxins (PCDDs), dibenzofurans (PCDFs), biphenyls (PCBs), and polycyclic aromatic hydrocarbons (PAHs). The objective of this study is to assess the Ah-agonistic effects in the sediments and identify the specific compounds or classes of compounds which might be responsible for the Ah-agonistic effects.

\section{Materials and methods}

\subsection{Sample collection and preparation}

Surface sediments ( $<10 \mathrm{~cm}$ depth) from 23 sites of Wenyu River, Beijing, China (Fig. 1), were collected in October, 2006 by a stainless steel grab and scooped into aluminum jars that had been prerinsed with dichloromethane (DCM). The samples were immediately transferred to the laboratory and kept at $-20^{\circ} \mathrm{C}$ until further analyses.

Total organic carbon (TOC) of the freeze-dried and sieved (425- $\mu \mathrm{m}$ sieve) sediments after removing the inorganic carbon with $21 \%$ phosphoric acid was analyzed by TOC analyzer (Appollo 9000, Tekmar Dohrmann Co., USA). The sediment samples were extracted with $200 \mathrm{~mL}$ DCM/acetone (1/1, v/v) with activated copper for desulfurization in a Soxhlet apparatus for $48 \mathrm{~h}$. A set of raw extract aliquots were preconcentrated on a rotary evaporator, solvent-exchanged to dimethyl sulfoxide (DMSO; Sigma-Aldrich Chemical Co., USA) under a gentle stream of nitrogen gas and stored at $-20^{\circ} \mathrm{C}$ for the H4IIE cell bioassay. Another set of aliquots were further cleaned by a multilayer silica gel column containing: $2 \mathrm{~g}$ of anhydrous sodium sulfate; $2 \mathrm{~g}$ of deactivated silica $(3.3 \%$ organic-free reagent water, w/w); $12 \mathrm{~g}$ of acidic silica (44\% sulphuric acid, w/w); $1 \mathrm{~g}$ of deactivated silica (3.3\% organicfree reagent water, $\mathrm{w} / \mathrm{w}$ ). The silica gel column was pre-eluted with $80 \mathrm{~mL}$ of hexane prior to adding the extract. The fraction eluted with $n$-hexane $(100 \mathrm{~mL})$ and DCM/hexane $(100 \mathrm{~mL}, 1: 9$ $\mathrm{v} / \mathrm{v}$ ) was the acid stable fraction intended for collection of the dioxin-like compounds, such as PCDDs, PCDFs, PCBs (US EPA, 1994). The eluates were concentrated and solvent-exchanged to DMSO for detecting the TCDD equivalents of acid stable fraction $\left(\mathrm{TEQ}_{\text {stable }} \mathrm{S}\right)$.

\subsection{H4IIE cell bioassay}

H4IIE cells were cultured in Dulbecco's modified Eagle medium (DMEM; Gibco, Germany) supplemented with $10 \%(\mathrm{v} / \mathrm{v})$ fetal bovine serum, $100 \mathrm{units} / \mathrm{mL}$ penicillin, and $100 \mu \mathrm{g} / \mathrm{mL}$ streptomycin. The routine maintenance of cells was as described elsewhere (Qiao et al., 2006; Gale et al., 2000). Cells were seeded into the 96 -well culture plates and stored at $37{ }^{\circ} \mathrm{C}$ with $5 \% \mathrm{CO}_{2}$ in an incubator (Sanyo, Japan), and the initial cell density was about 3000 cells per well. After $24 \mathrm{~h}$, when a monolayer was formed consisting of $70-80 \%$ cells cover, the original culture medium was removed and replaced by a culture medium containing 2,3,7,8-tetrachlorodibenzo- $p$ dioxin (TCDD) standard solutions or the test solutions. The standard solutions were prepared by serial dilution of TCDD stock solution that could yield a full dose-response curve of EROD induction (TCDD: 0-140 pg/mL in culture). Six concentrations of the raw extracts were prepared by three fold dilution, and four concentrations for the cleanup fraction. In each well, the final concentration of DMSO was $0.5 \%$. Meantime, a $0.5 \%$ DMSO solution was also used as the solvent control. Each test solution was assayed in triplicate, and three solvent controls (negative control) were assayed simultaneously on each 96-well plate. The edges of the 96-well culture plates were wrapped with parafilm and were incubated for $72 \mathrm{~h}$ at $37^{\circ} \mathrm{C}$. After incubation, EROD enzyme activity was analyzed following the methods of Qiao et al. (2006). Protein concentrations were determined as described by Bradford, 1976. Resorufin standard curve was analyzed at the same time to convert fluorescent units to picomoles of resorufin. The bioassay-derived TCDD equivalents were determined according to Tillitt et al. (1991) by comparing the induction of 


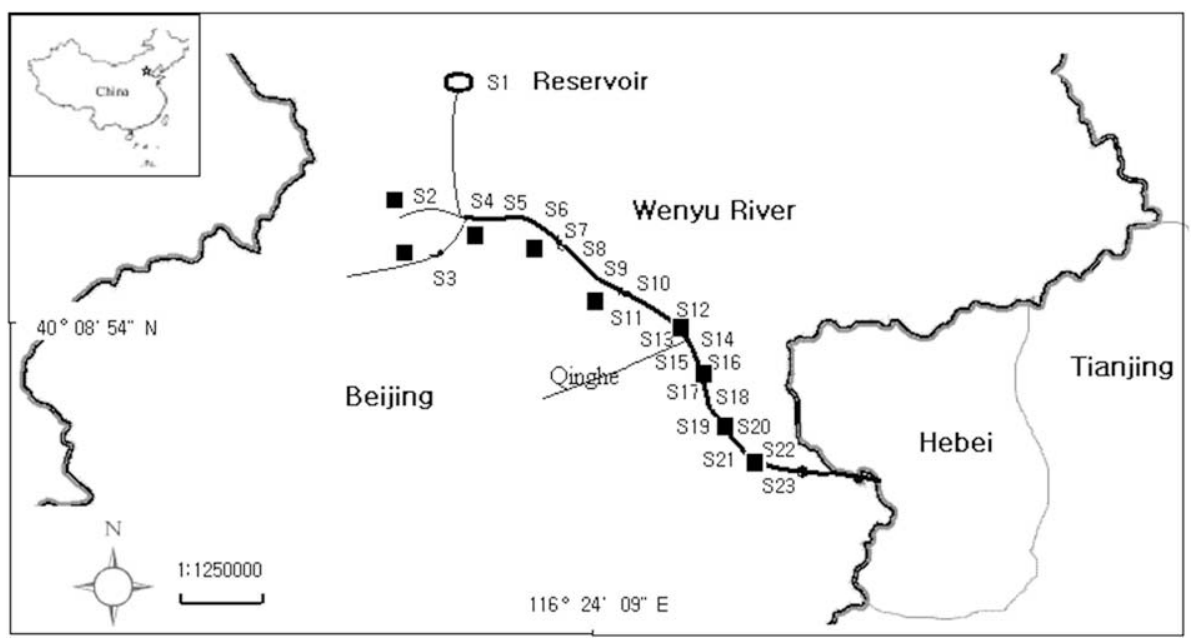

Fig. 1 - Map of the Wenyu River, in Beijing, China and sampling locations. a are the wastewater outfalls, outflow of which is more than $10,000 \mathrm{~m}^{3} / \mathrm{d}$.

EROD activity caused by environmental sample extracts with that caused by authentic TCDD standards. The minimum detectable concentration was $0.03 \mathrm{pg} /$ well. Blanks for extraction and fractionation procedure were included, and these Ah-agonistic effect levels were all under the detectable limit. The average deviation of tested samples between duplicate measurements was within $\pm 25 \%$.

\subsection{Chemical analysis}

According to the screening result of the H4IIE cell bioassay and site locality of the river, five sediment samples (site 3 , site 7 , site 10 , site 18, and site 23) were selected for further analysis. For PAHs analysis, a set of raw extract aliquots were subjected to cleanup on a silica gel/aluminum oxide column to obtain PAHs fraction by elution with $70 \mathrm{~mL}$ of hexane/DCM $(7 / 3, \mathrm{v} / \mathrm{v})$. The eluates were evaporated and were dissolved in hexane for GC-MS analysis (Qiao et al., 2005). The average recoveries of PAHs in matrix spikes were from $69 \pm 7 \%$ to $86 \pm 8 \%$. Concentrations of the analytes were not adjusted by recoveries.

For PCBs, PCDDs, and PCDFs analysis, raw extracts were cleaned up by multilayered silica gel, acid alumina, and florisil chromatographic columns and were analyzed by HRGC/HRMS on an Agilent 6890 gas chromatography coupled with an Autospec Ultima mass spectrometer (Waters Micromass, Manchester, UK) (Zhang and Jiang, 2005). All data were subjected to strict quality control procedures to meet EPA requirements for field research. Phenanthrene-d10 and ${ }^{13} \mathrm{C}$ labeled surrogate standards were spiked to determine recoveries. All blanks for cleanup procedure were analyzed to check for interference or contamination arising from solvents or glassware during the working procedure. Detailed instrumental conditions and method evaluation are described elsewhere (Qiao et al., 2005; Zhang and Jiang, 2005). Recoveries of ${ }^{13} \mathrm{C}$-PCBs, PCDDs, and PCDFs were from $53 \pm 5 \%$ to $74 \pm 12 \%$, $63 \pm 9 \%$ to $107 \pm 21 \%$, and $61 \pm 10 \%$ to $95 \pm 18 \%$, respectively.

The TEQs of PCDDs, PCDFs, PCBs were calculated by multiplying the measured concentrations by the corresponding relative potencies (REPs) of $72 \mathrm{~h}$ exposure time for the H4IIE cell bioassay (Tillitt and Giesy, 1991; Tillitt et al., 1996). PAHs which have Ah-agonistic effect, i.e. benzo[k]fluoranthene $(\mathrm{BkF})$, benzo[a]pyrene $(\mathrm{BaP})$, benzo[b]fluoranthene $(\mathrm{BbF})$, chrysene $(\mathrm{Chr})$, benz[a]anthracene $(\mathrm{BaA})$, indeno[1,2,3-cd]pyrene (IcdP), and dibenz[a,h]anthracene (DahA) are commonly metabolized by cytochrome P4501A1. In the present study, REPs of PAHs related to TCDD were used to estimate TEQs contributed by individual PAHs. REPs of PAHs obtained in our laboratory (Li et al., 2006) were as much as those from in vitro recombinant H4IIE cells bioassay (Villeneuve et al., 2002) with the exposure time of $72 \mathrm{~h}$. The chemical analysis-derived toxic equivalents (TEQ $Q_{c h e m} \mathrm{~s}$ ) were obtained as the sum of TEQs from the individual compounds including PCBs, PCDDs, PCDFs, and PAHs.

\section{Results and discussion}

\subsection{TEQ $\mathrm{Trw}_{\text {raw }} \mathrm{s}$ and $\mathrm{TEQ} \mathrm{Q}_{\text {stable }} \mathrm{S}$ for the H4IIE cell bioassay}

Live cell amount and cell morphology in sample wells were examined and compared with those of the negative control to assess the cytotoxicity of extracts. No apparent cytotoxicity was observed for any extract except two raw extracts at the highest concentration exposure. The experiment showed that good dose-response relationships were obtained by testing samples at multiple dilutions. Significant EROD responses were induced in the H4IIE for all raw extracts and acid stable fractions (Table 1).

The TCDD equivalents of raw extracts $\left(\mathrm{TEQ}_{\mathrm{raw}} \mathrm{s}\right)$ ranged from 8.5 to $336.0 \mathrm{pg} / \mathrm{g}$ dry weight (dw). They were closely related to TOC contents of the sediment samples $(r=0.89$, $P<0.01$ ) (Fig. 2). According to the report on aquatic environmental quality of Wenyu River in 2005 (BHRI, 2006), the total amount of wastewaters that was discharged into the river was more than $1.7 \times 10^{5} \mathrm{~m}^{3}$ per day, and about half of that with high organic matter content were dumped directly without any treatment. Among that, domestic sewage accounted for 


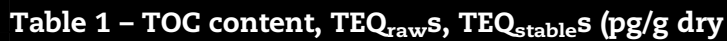
weight, $n=3$ ) and their percentages of $\mathrm{TEQ}_{\text {raw }} \mathrm{s}$ in sediments from Wenyu River, Beijing, China.

Sites TOC content TEQ raws TEQ stable (\%)

\begin{tabular}{lrcrl}
\hline S1 & 1.5 & $30.6 \pm 7.3$ & $7.2 \pm 0.8$ & 23.5 \\
S2 & 28.4 & $328.0 \pm 31.6$ & $63.8 \pm 5.9$ & 19.5 \\
S3 & 33.2 & $336.0 \pm 25.9$ & $60.5 \pm 7.5$ & 18.0 \\
S4 & 1.1 & $79.0 \pm 19.7$ & $17.4 \pm 2.0$ & 22.0 \\
S5 & 4.5 & $51.4 \pm 9.3$ & $12.3 \pm 1.9$ & 23.9 \\
S6 & 1.2 & $37.8 \pm 5.4$ & $9.8 \pm 1.5$ & 25.9 \\
S7 & 1.6 & $71.5 \pm 21.6$ & $22.6 \pm 3.4$ & 31.6 \\
S8 & 0.4 & $24.8 \pm 5.2$ & $8.6 \pm 0.7$ & 34.7 \\
S9 & 0.3 & $8.7 \pm 1.6$ & $3.0 \pm 0.4$ & 34.3 \\
S10 & 15.1 & $52.8 \pm 9.0$ & $14.8 \pm 0.9$ & 28.0 \\
S11 & 1.8 & $11.2 \pm 2.7$ & $3.6 \pm 0.3$ & 32.2 \\
S12 & 0.9 & $8.5 \pm 2.8$ & $2.7 \pm 0.4$ & 31.9 \\
S13 & 0.8 & $46.3 \pm 13.9$ & $6.3 \pm 1.2$ & 13.6 \\
S14 & 2.8 & $48.8 \pm 5.2$ & $13.1 \pm 1.1$ & 26.9 \\
S15 & 2.3 & $58.2 \pm 2.2$ & $12.7 \pm 1.6$ & 21.8 \\
S16 & 27.1 & $208.6 \pm 25.7$ & $37.6 \pm 3.9$ & 18.0 \\
S17 & 8.1 & $75.1 \pm 10.6$ & $16.9 \pm 1.4$ & 22.5 \\
S18 & 2.7 & $43.6 \pm 9.2$ & $9.4 \pm 0.9$ & 21.6 \\
S19 & 18.1 & $94.0 \pm 13.0$ & $25.1 \pm 3.1$ & 26.7 \\
S20 & 15.3 & $191.3 \pm 21.2$ & $59.3 \pm 6.1$ & 31.0 \\
S21 & 10.1 & $148.6 \pm 4.0$ & $42.0 \pm 3.8$ & 28.3 \\
S22 & 1.2 & $62.8 \pm 4.8$ & $6.5 \pm 1.7$ & 10.3 \\
S23 & 12.1 & $212.5 \pm 32.1$ & $61.6 \pm 7.1$ & 29.0 \\
\hline
\end{tabular}

about 50\%, industrial effluents about 30\% and livestock wastewater about $20 \%$. Moreover, the high TOC content (e.g. up to $33.2 \%$ at site 3 ) in some sediment samples along the river (Table 1) and the correlation between TOC and TEQraws also suggested that the wastewater discharge along the river (Fig. 1) is a potential important source of Ah-agonists. The screening results of raw sediment extracts for this river indicated that the total Ah-agonist effects were higher than those of sediments from Taihu Lake which is a typical shallow freshwater lake (17.8-35.8 pg/g dw) (Qiao et al., 2006), similar to those of soils from a large-scale e-waste disposal center in China (91.0-383.0 pg/g dw) (Shen et al., 2008), and lower than those of sediments from the Hudson-Raritan estuary and Newark Bay, USA (170-43,000 pg/g dw) (Gale et al., 2000). These comparisons showed that Ah-agonistic effect was accumulated in sediment of Wenyu River to a severe degree.

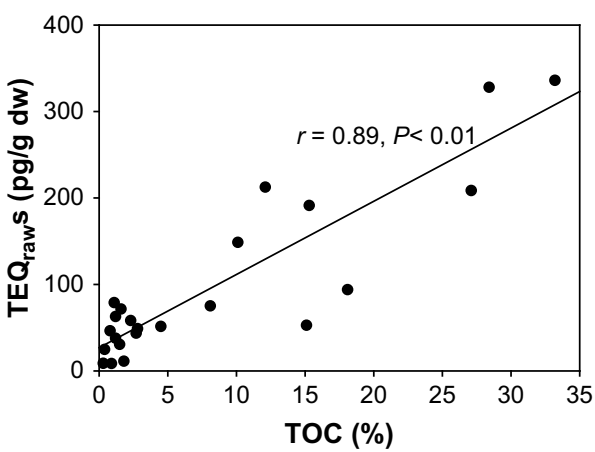

The acid labile compounds unstable to oxidative breakdown could be removed by the fractionation procedure and the acid stable compounds were effectively isolated from the raw extracts (US EPA, 1994). The TCDD equivalents of the

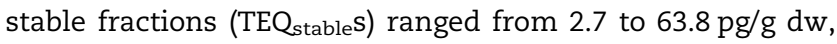
which accounted for $10.3-34.7 \%$ of the TEQ $\mathrm{Q}_{\text {raw }} \mathrm{s}$. A relationship between the TEQ $\mathrm{Ttable}_{\text {s }}$ and $\mathrm{TEQ}_{\text {raw }} \mathrm{S}(r=0.94, \mathrm{P}<0.01)$ was observed (Fig. 2). The past work indicated that the major stable Ah-agonists are mainly the dioxin-like compounds such as PHAHs (Behnisch et al., 2001) which are persistent organic pollutants (POPs), can be bioaccumulated, and may be transferred along the food chain. The food-web magnification of these POPs had become a significant concern for wildlife and humans. Here, dioxins sediment guidelines from Canada, USA and the Netherlands with TEQ values of $0.85,2.5,13 \mathrm{pg} / \mathrm{g}$, respectively (CCME, 2002; US EPA, 1993; DNHC, 1996) were used to evaluate preliminarily the environmental risk of dioxins in the sediments from Wenyu River. The $\mathrm{TEQ}_{\text {stable }} \mathrm{S}$ at all sites sampled in this study were above both of the Canadian and American guidelines, and more than half of the sites exceeded the least Dutch guidelines. It can be predicted that the sediments might pose an unacceptable risk to aquatic organisms and their predators, and adverse biological impacts are likely to occur to the sensitive species.

On the other hand, it was found that more than $60 \%$ of $\mathrm{TEQ}_{\text {raw }}$ could be attributed to labile fractions in sediments of this river. Previous studies also observed that some classes of Ah-agonists distributed in the labile fraction (or polar fraction) (Khim et al., 1999; Hurst et al., 2004), which may include heterocyclic amines, oxidized carotenoids, indoles and humic acids and so on (Behnisch et al., 2001; Bittner et al., 1998). Moreover, a large portion of labile compounds could be metabolized by the H4IIE cells after $72 \mathrm{~h}$ incubation (Payne et al., 1987). If the incubation time is reduced, higher percentage of $\mathrm{TEQ}_{\mathrm{raw}} \mathrm{s}$ will be attributed to the labile fraction (Hurst et al., 2004). These observations added to a growing body of evidence which indicated that there were large quantities of labile Ah-agonists in sediments from this area. Although the labile compounds are susceptible to biodegradation and can not be bioaccumulated in aquatic organisms, continuous exposure to these compounds may result in adverse effects similar to those caused by PHAHs, as was shown in brown bullhead Ameiurus nebulosus (Grady et al., 1992).

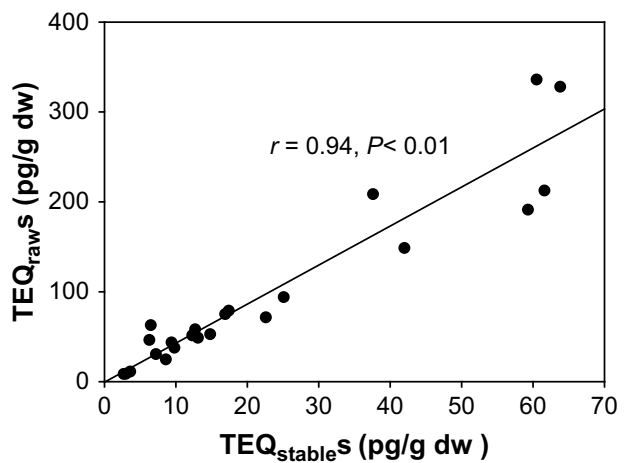

Fig. 2 - Relationships between TOC content and TEQ ${ }_{r a w} s$, and between $T E Q_{\text {stable }} s$ and $T E Q_{\text {raw }} s$ in the sediments from Wenyu River, Beijing, China. 


\subsection{Concentrations of PCBs, PCDDs, PCDFs and PAHs}

The concentrations of PCBs, PCDDs, PCDFs and PAHs for the selected sediment samples were listed in Table 2. The concentrations of PCDDs and PCDFs ranged from 110.8 to $222.9 \mathrm{pg} / \mathrm{g} \mathrm{dw}$ and 185.4 to $245.7 \mathrm{pg} / \mathrm{g} \mathrm{dw}$, respectively. In comparison, total concentrations of PCDD/Fs were much lower than those in the heavily polluted sediments from Ya-er lake
(China) (Wu et al., 2001) and at the same level to two rivers in Catalonia (Eljarrat et al., 2001a). The concentrations of 27 PCBs ranged from 32.0 to $76.6 \mathrm{ng} / \mathrm{g} \mathrm{dw}$, which were two or three orders of magnitude higher than those from sediments from Taihu Lake (China) (Qiao et al., 2006), and at the same level to Northwest Mediterranean sediments in Spain (Eljarrat et al., 2001b). In the case of PAHs, concentrations were as much as those in sediments of Taihu Lake (China) (Qiao et al., 2005) and

\section{Table 2 - Concentrations and chemical analysis-derived TEQ ${ }_{c h e m} s^{a}$ for PCDDs, PCDFs, PCBs and PAHs in sediments for} Wenyu River, Beijing, China.

\begin{tabular}{|c|c|c|c|c|c|c|}
\hline Chemicals & REPs $^{\mathrm{b}}$ & Site 3 & Site 7 & Site 10 & Site 18 & Site 23 \\
\hline \multicolumn{7}{|l|}{ PCDDs } \\
\hline 2378-TCDD & 1 & 0.3 & 0.7 & 0.2 & 0.3 & 0.2 \\
\hline 12378-PeCDD & 0.42 & 0.3 & 0.6 & 0.3 & 0.5 & 0.8 \\
\hline 123478-HxCDD & 0.083 & 0.2 & 0.3 & 0.7 & 0.4 & 0.4 \\
\hline 123678-HxCDD & 0.024 & 1.0 & 0.3 & 1.5 & 0.9 & 0.9 \\
\hline 123789-HxCDD & 0.034 & 0.8 & 0.3 & 0.6 & 0.8 & 0.7 \\
\hline 1234678-HpCDD & 0.023 & 12.1 & 4.1 & 11.7 & 7.7 & 8.6 \\
\hline OCDD & & 89.0 & 56.5 & 141.0 & 60.6 & 99.1 \\
\hline$\sum$ PCDDs & & 167.1 & 110.8 & 222.9 & 132.5 & 185.8 \\
\hline TEQ $_{\text {PCDDs }}$ & & 0.8 & 1.1 & 0.7 & 0.7 & 0.8 \\
\hline \multicolumn{7}{|l|}{ PCDFs } \\
\hline 2378-TCDF & 0.2 & 3.0 & 3.2 & 5.2 & 3.3 & 2.6 \\
\hline 12378-PeCDF & 0.2 & 2.2 & 1.9 & 2.3 & 2.0 & 2.0 \\
\hline 23478-PeCDF & 1.4 & 4.0 & 0.7 & 3.8 & 2.8 & 2.7 \\
\hline 123478-HxCDF & 0.02 & 3.4 & 2.5 & 4.0 & 3.1 & 3.5 \\
\hline 123678-HxCDF & 0.06 & 3.0 & 2.1 & 3.2 & 2.9 & 3.3 \\
\hline 234678-HxCDF & 0.3 & 2.9 & 1.6 & 3.7 & 3.2 & 4.0 \\
\hline 123789-HxCDF & 0.2 & 1.1 & 0.8 & 1.2 & 1.0 & 0.4 \\
\hline 1234678-HpCDF & 0.3 & 11.9 & 7.8 & 15.3 & 11.3 & 14.4 \\
\hline 1234789-HpCDF & 0.02 & 1.5 & 0.6 & 2.0 & 2.0 & 1.6 \\
\hline OCDF & & 14.7 & 9.1 & 30.4 & 25.1 & 25.3 \\
\hline$\sum \mathrm{PCDFs}$ & & 234.8 & 185.4 & 245.7 & 219.5 & 226.2 \\
\hline TEQ ${ }_{P C D F s}$ & & 11.5 & 5.1 & 13.0 & 9.8 & 10.5 \\
\hline \multicolumn{7}{|l|}{ PCBs } \\
\hline PCB81 & 0.0019 & 4.6 & 1.4 & 3.6 & 5.4 & 4.4 \\
\hline PCB77 & 0.000018 & 5.3 & 1.8 & 6.7 & 3.8 & 4.9 \\
\hline PCB123 & 0.000012 & 1.1 & 0.9 & 1.0 & 1.4 & 1.2 \\
\hline PCB118 & 0.00000035 & 2.5 & 1.0 & 1.9 & 2.6 & 1.1 \\
\hline PCB114 & 0.000001 & 0.3 & 0.0 & 0.5 & 0.0 & 0.0 \\
\hline PCB105 & 0.000008 & 1.5 & 0.9 & 2.2 & 1.8 & 3.9 \\
\hline PCB126 & 0.022 & 1.3 & 0.3 & 0.9 & 0.9 & 1.1 \\
\hline PCB167 & 0.000009 & 2.3 & 1.1 & 1.8 & 1.5 & 1.9 \\
\hline PCB156 & 0.000055 & 2.1 & 0.8 & 2.7 & 1.6 & 1.2 \\
\hline РCB157 & 0.000015 & 1.5 & 1.8 & 2.1 & 2.3 & 2.0 \\
\hline PCB169 & 0.00047 & 0.2 & 0.0 & 0.2 & 0.4 & 0.3 \\
\hline PCB189 & 0.00001 & 3.2 & 0.9 & 3.7 & 2.5 & 0.3 \\
\hline$\sum 27 \mathrm{PCBs}$ & & 76.6 & 32.0 & 63.7 & 65.5 & 60.0 \\
\hline $\mathrm{TEQ}_{\mathrm{PCBs}}$ & & 37.7 & 9.4 & 27.1 & 30.5 & 33.0 \\
\hline \multicolumn{7}{|l|}{ PAHs } \\
\hline $\mathrm{BaA}$ & 0.0000014 & 149.2 & 33.0 & 95.0 & 83.5 & 239.4 \\
\hline Chr & 0.0000015 & 272.4 & 33.0 & 113.1 & 112.1 & 399.8 \\
\hline $\mathrm{BbF}$ & 0.0000028 & 313.5 & 68.6 & 136.9 & 144.7 & 354.6 \\
\hline $\mathrm{BkF}$ & 0.00011 & 77.7 & 20.8 & 47.2 & 41.4 & 137.7 \\
\hline $\mathrm{BaP}$ & 0.0000039 & 161.0 & 25.0 & 90.6 & 98.3 & 203.6 \\
\hline IcdP & 0.00003 & 33.0 & 70.7 & 53.7 & 22.0 & 79.4 \\
\hline DahA & 0.000004 & 22.5 & 16.8 & 58.0 & 27.3 & 54.4 \\
\hline$\sum 16 \mathrm{PAHs}$ & & 2350.2 & 657.6 & 1911.2 & 1688.2 & 3700.8 \\
\hline $\mathrm{TEQ}_{\mathrm{PAHs}}$ & & 11.7 & 4.9 & 8.1 & 6.4 & 20.5 \\
\hline TEQ $Q_{\text {stable }} \mathrm{S}$ & & 63.8 & 14.8 & 37.6 & 59.3 & 61.6 \\
\hline $\mathrm{TEQ}_{\text {raw }} \mathrm{S}$ & & 336.0 & 52.8 & 208.6 & 191.3 & 212.5 \\
\hline
\end{tabular}

a Concentrations were expressed as ng/g dry weight (dw) for PCBs and PAHs, pg/g dw for PCDDs, PCDFs, and TEQs.

b REPs were obtained from references (Tillitt and Giesy, 1991; Tillitt et al., 1996; Li et al., 2006). 
Northwest Mediterranean (Eljarrat et al., 2001b). It was found through these comparisons that Wenyu River had been contaminated by PCDD/Fs, PCBs, and PAHs at a relatively high level. Furthermore, from the study by Dai et al. (2007) concentrations of PCDD/Fs and PAHs in sludge from six wastewater treatment plants in Beijing with total treatment capacity of $1.5 \times 10^{6} \mathrm{~m}^{3}$ per day ranged from 330 to $4245 \mathrm{pg} / \mathrm{g}$ dw with an average of $1337 \mathrm{pg} / \mathrm{dw}$ and $2467-25,924 \mathrm{ng} / \mathrm{g}$ dw with an average of $8310 \mathrm{pg} / \mathrm{g} \mathrm{dw}$, respectively. Most of those effluents would be discharged directly or indirectly into Wenyu River. It is reasonable to predict that like Ah-agonists the wastewater discharge is an important source for these target analytes.

\subsection{TEQ $Q_{\text {raw }} s, T E Q_{\text {stable }} s$, and $T E Q_{\text {chem }} s$}

Bioassay-derived TCDD equivalents were compared to instrumentally derived TEQs in a mass balance analysis in order to help characterizing of Ah-agonists in Wenyu River sediments. By chemical analysis and TEQ calculation with REPs, it was observed that TEQs contributed by PCDDs ranged from 0.7 to $1.1 \mathrm{pg} / \mathrm{g} \mathrm{dw}$, those by PCDFs from 5.1 to $13.0 \mathrm{pg} / \mathrm{g} \mathrm{dw}$, those by PCBs from 9.4 to $37.7 \mathrm{pg} / \mathrm{g} \mathrm{dw}$, and those by PAHs from 4.9 to $20.5 \mathrm{pg} / \mathrm{g} d \mathrm{w}$ (Table 2). The sum TEQs of PCDDs, PCDFs and PCBs ranged from 15.6 to $50.0 \mathrm{pg} / \mathrm{g} \mathrm{dw}$, and accounted for 69.1-108.6\% of TEQ stable with a correlation $(r=0.92, P<0.01)$ (Fig. 3). Given the potential uncertainty in the TEQ estimates, our results indicated that the analyzed PHAHs in the Wenyu River could account by and large for the Ah-agonistic effects of acid stable fraction observed in the H4IIE cell bioassay.

In detail, the individual percentages of TEQs calculated from PCDDs, PCDFs and PCBs to their sum TEQs were 1.5-6.9\%, 23.0-33.0\% and 60.1-75.4\%, respectively. Among the three classes of PHAHs, PCBs and PCDFs were two important classes of Ah-agonists in the acid stable fraction, where the greatest contribution to the $\mathrm{TEQ}_{\mathrm{PCDF}}$ came from the congeners 2,3,4,7,8-PeCDF and 1,2,3,4,6,7,8-HpCDF, to the TEQPCBs from the congeners PCB126 and PCB81. The congeners 2,3,7,8TCDD , 1,2,3,7,8-PeCDD and 1,2,3,4,6,7,8-HpCDD were the main contributors to TEQ ${ }_{\text {PCDDs }}$ from PCDD congeners, although their contribution was not high for the TEQ stables. PCDD/Fs and PCBs were found to be responsible for Ah-agonist effects,

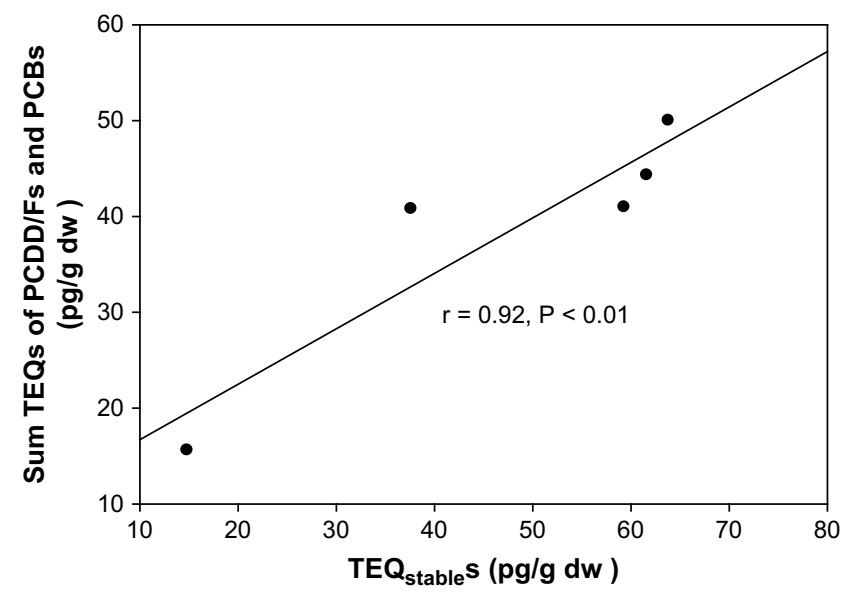

Fig. 3 - Relationship between TEQ stables and the sum TEQs of PCDD/Fs and PCBs. respectively in sediments from Hyeongsan River, Korea (Koh et al., 2004) and in soil of E-waste recycling sites from Taizhou, China (Shen et al., 2008). Brack et al. $(2002,2008)$ had identified different key Ah-agonists, i.e. PCDD/Fs, and polychlorinated naphthalenes in sediments from different localities in Germany. It should be noted that there are a number of other classes of PHAHs such as polybrominated diphenyl ethers (PBDEs) and polybrominated biphenyls (PBBs) that can interact with the Ah receptor and potentially cause Ahagonist effect (Behnisch et al., 2001). These compounds might have also contributed to the Ah-agonistic effects.

On the other hand, PAHs as a kind of acid labile compounds were found to be an important class of Ah-agonists in sediments from Taihu Lake, China (Qiao et al., 2006) and from the Hudson-Raritan estuary and Newark Bay, USA (Gale et al., 2000). For the acid labile fractions of Wenyu River, TEQs contributed by PAHs ranged from 4.9 to $20.5 \mathrm{pg} / \mathrm{g} \mathrm{dw}$, and only accounted for 3.3-9.6\% of TEQ ${ }_{\text {raw }}$ s. This showed that the vast majority of Ah-agonist effect induced by acid labile fraction was attributable to other labile compounds. Indirubin as an extremely potent acid labile AhR agonist was widely detected in effluents of sewage treatment plants with concentrations of 0.6-5.4 ng/L in Beijing, and 0.7-3.7 ng/L in Qinghe River that is a main tributary of Wenyu River (Wu et al., 2008). Therefore, indirubin could be an important Ah-agonist in the labile fraction, and further studies are still needed to put emphasis on identification of other Ah-agonists in this fraction.

\section{Conclusions}

The combination of bioassays and chemical analyses through comparing instrumentally derived TEQs to bioassay-derived TEQs suggested that the acid stable fraction and labile fraction contributed together to the total Ah-agonistic effects in the sediments, and PCBs and PCDFs might be the two important components in acid stable Ah-agonists. The proposed approach using H4IIE cell assay and chemical analysis used in this study could be a useful tool in quantitatively screening and characterization of Ah-agonists in river sediments for monitoring and regulatory purposes.

\section{Acknowledgements}

This study was supported by the National Basic Research Program of China (2007CB407304) and National Natural Science Foundation of China (20737003 and 40703025).

\section{R E F E R E N C E S}

Behnisch, P., Hosoe, K., Sakai, S., 2001. Combinatorial bio/ chemical analysis of dioxin and dioxin-like compounds in waste recycling, feed/food, humans/wildlife and the environment. Environment International 27, 495-519.

Beijing Hydraulic Research Institute (BHRI), 2006. Guidelines of Water BodyRemediation and Water Resource Utilization for Wenyu River, Beijing, China, pp. 30-50 (in Chinese). 
Bittner, M., Janošek, J., Hilscherová, K., Giesy, J., Holoubek, I., Bláha, L., 2006. Activation of Ah receptor by pure humic acids. Environmental Toxicology 21, 338-342.

Blanchard, M., Teil, M., Ollivon, D., Garban, B., Chestérikoff, C., Chevreuil, M., 2001. Origin and distribution of polyaromatic hydrocarbons and polychlorobiphenyls in urban effluents to wastewater treatment plants of the Paris area (France). Water Research 35, 3679-3687.

Brack, W., Schirmer, K., 2003. Effect-directed identification of oxygen and sulphur heterocycles as major polycyclic aromatic cytochrome P4501A-inducers in a contaminated sediment. Environmental Science \& Technology 37, 3062-3070.

Brack, W., Schirmer, K., Kind, T., Schrader, S., Schüürmann, G., 2002. Effect-directed fractionation and identification of cytochrome P450-inducing halogenated aromatic hydrocarbons in a contaminated sediment. Environmental Toxicology and Chemistry 21, 2654-2662.

Brack, W., Bláha, L., Giecy, P., Grote, M., Moeder, M., Schrader, S., Hecker, M., 2008. Polychlorinated naphthalenes and other dioxin-like compounds in Elbe River sediments. Environmental Toxicology and Chemistry 27, 519-528.

Bradford, M.M., 1976. A rapid and sensitive method for the quantification microgram quantities of protein utilizing the principle of protein-dye binding. Analytical Biochemistry 72, 248-254.

Canadian Council of Ministers of the Environment (CCME), 2002. Canadian environmental quality guidelines for polychlorinated dibenzo-p-dioxins and polychlorinated dibenzofurans (PCDD/Fs): Canadian sediment quality guidelines for the protection of aquatic life, 2001.

Dai, J., Xu, M., Chen, J., Yang, X., Ke, Z., 2007. PCDD/F, PAH and heavy metals in the sewage sludge from six wastewater treatment plants in Beijing, China. Chemosphere 66, 353-361.

Denison, M., Pandini, A., Nagy, S., Baldwin, E., Bonati, L., 2002. Ligand binding and activation of the Ah receptor. ChemicoBiological Interactions 141, 3-24.

Dutch National Health Council (DNHC), 1996. Dioxins: polychlorinated dibenzo-p-dioxin, dibenzofuran and dioxinlike polychlorinated biphenyls. Report 1996/10.

Eljarrat, E., Caixach, J., Rivera, J., 2001a. Evaluation of dioxin contamination in sewage sludge discharges on coastal sediments from Catalonia, Spain. Water Research 35, 2799-2803.

Eljarrat, E., Caixach, J., Rivera, J., 2001b. Toxic potency assessment of non- and mono-ortho PCBs PCDDs, PCDFs, and PAHs in Northwest Mediterranean sediments (Catalonia, Spain). Environmental Science \& Technology 35, 3589-3594.

Gale, R.W., Long, E.R., Schwartz, T.R., Tillitt, D.E., 2000. Evaluation of planar halogenated and polycyclic aromatic hydrocarbons in estuarine sediments using ethoxyresorufin- O-deethylase induction of H4IIE cells. Environmental Toxicology and Chemistry 19, 1348-1359.

Giesy, J., Hilscherova, K., Jones, P.D., Kannan, K., Machala, M., 2002. Cell bioassays for detection of aryl hydrocarbon (AhR) and estrogen receptor (ER) mediated activity in environmental samples. Marine Pollution Bulletin 45, 3-16.

Grady, A., Fabacher, D., Frame, G., Steadman, B., 1992. Morphological deformities in brown bullheads administered dietary $\alpha$ Naphthoflavone. Journal of Aquatic Animal Health 4, 7-16.

Hurst, M., Balaam, J., Chan-Man, Y., Thain, J., Thomas, K., 2004. Determination of dioxin and dioxin-like compounds in sediments from UK estuaries using a bio-analytical approach: chemical-activated luciferase expression (CALUX) assay. Marine Pollution Bulletin 49, 648-658.

Kakimoto, H., Oka, H., Miyata, Y., Yonezawa, Y., Niikawa, A., Kyudo, H., Tang, N., Toriba, A., Kizu, R., Hayakawa, K., 2006. Homologue and isomer distribution of dioxins observed in water samples collected from Kahokugata
Lagoon and inflowing rivers, Japan. Water Research 40, 1929-1940.

Khim, J., Villeneuve, D., Kannan, K., Koh, C., Giecy, J., 1999. Characterization and distribution of trace organic contaminants in sediment from Masan Bay, Korea. 2. In vitro gene expression assays. Environmental Science \& Technology 33, 4206-4211.

Koh, C., Khim, J., Kannan, K., Villeneuve, D., Senthilkumar, K., Giesy, J., 2004. Polychlorinated dibenzo- $p$-dioxins (PCDDs), dibenzofurans (PCDFs), biphenyls (PCBs), and polycyclic aromatic hydrocarbons (PAHs) and 2,3,7,8-TCDD equivalents (TEQs) in sediment from the Hyeongsan River, Korea. Environmental Pollution 132, 489-501.

Li, J., Qiao, M., Cui, Q., Ma, M., Wang, Z., 2006. Detection of toxic equivalent factors for PAHs and studies on its usage in the sediment of Meiliang Bay, Taihu Lake. Asian Journal of Ecotoxicology 1, 12-16.

Payne, J.F., Fancey, L.L., Rahimtula, A.D., Porter, E.L., 1987. Review and perspective on the use of mixed-function oxygenase enzymes in biological monitoring. Comparative Biochemistry and Physiology C 86, 233-245.

Qiao, M., Wang, C.X., Huang, S.B., Wang, D.H., Wang, Z.J., 2005. Composition, sources and potential toxicological significance of PAHs in the surface sediments of the Meiliang Bay, Taihu Lake, China. Environment International 32, 28-33.

Qiao, M., Chen, Y., Zhang, Q., Huang, S., Ma, M., Wang, C., Wang, Z., 2006. Identification of Ah receptor agonists in sediment of Meiliang Bay, Taihu Lake, China. Environmental Science \& Technology 40, 1415-1419.

Safe, S.H., 1990. Polychlorinated biphenyls (PCBs), dibenzo- $p$ dioxins (PCDDs), dibenzofurans (PCDFs) and related compounds: environmental and mechanistic considerations which support the development of toxicity equivalency factors (TEFs). Critical Reviews in Toxicology 21, 51-88.

Shen, C., Huang, S., Wang, Z., Qiao, M., Tang, X., Yu, C., Shi, D., Zhu, Y., Shi, J., Chen, X., Setty, K., Chen, Y., 2008. Identification of Ah receptor agonists in soil of e-waste recycling sites from Taizhou Area in China. Environmental Science \& Technology 42, 49-55.

Tillitt, D.E., Giesy, J., 1991. Characterization of the H4IIE rat hepatoma cell bioassay as a tool for assessing toxic potency of planar halogenated hydrocarbons in environmental samples. Environmental Science \& Technology 25, 87-92.

Tillitt, D.E., Gale, R.W., Meadows, J.C., Zajicek, J.L., Peterman, P., Heaton, S., Jones, P., Bursian, S., Kubiak, T., Giecy, J., Aulerich, R., 1996. Dietary exposure of mink to carp from Saginaw Bay. 3. Characterization of dietary exposure to planar halogenated hydrocarbons, dioxin equivalents, and biomagnification. Environmental Science \& Technology 30, 283-291.

U.S. Environmental Protection Agency (EPA), 1993. Interim Report on Data and Methods for Assessment of 2,3,7,8-

Tetrachlorodibenzo- p-dioxin Risks to Aquatic Life and Associated Wildlife. EPA/600/R-93/055.

U.S. Environmental Protection Agency (EPA), 1994. Method 1613. Tetra Through Octachlorinated Dioxins and Furans by Isotopic Dilution HRGC-CHRMS. Washington DC.

U.S. Environmental Protection Agency (EPA), 1998. The Inventory of Sources of Dioxin in the United States. EPA/600/P-98/002Aa.

Van den Berg, M., Birnbaum, L., Bosveld, A.T.C., Brunström, B., Cook, F., Feely, M., Giesy, J., Hanberg, A., Hasegawa, R., Kennedy, S.W., Kubiak, T., Larsen, J.C., van Leeuwen, F.X.R., Liem, A.K.D., Nolt, C., Peterson, R.E., Poellinger, L., Safe, S., Schrenk, D., Tillitt, D., Tysklind, M., Younes, M., Waern, F., Zacharewski, T., 1998. Toxic equivalency factors (TEFs) for PCBs, PCDDs, PCDFs for humans and wildlife. Environmental Health Perspectives 103, 775-792. 
Villeneuve, D., Khim, J., Kannan, K., Giesy, J., 2002. Relative potencies of individual polycyclic aromatic hydrocarbons to induce dioxin-like and estrogenic responses in three cell lines. Environmental Toxicology 17, 128-137.

Wu, W., Schramm, K., Xu, Y., Kettrup, A., 2001. Mobility and profiles of polychlorinated dibenzo- $p$-dioxins and dibenzofurans in sediment of Ya-er lake, China. Water Research 35, 3025-3033.
Wu, J., Chang, H., Wang, L., Wu, S., Shao, B., Zhou, J., Zhao, Y., 2008. Detection, occurrence and fate of indirubin in municipal sewage treatment plants. Environmental Science \& Technology 42, 8339-8344.

Zhang, Q.H., Jiang, G.B., 2005. Polychlorinated dibenzo- p-dioxins/ furans and polychlorinated biphenyls in sediments and aquatic organisms from the Taihu Lake, China. Chemosphere $61,314-322$. 